Published by the UFS

http://journals.ufs.ac.za/index.php/trp

(c) Creative Commons With Attribution (CC-BY)

How to cite: Molefe N \& Nkhahle, S. 2019. Municipal urban land release and acquisition - SALGA's

proposals to facilitate spatial transformation and inclusive economic growth through efficient urban land

governance and management approaches. Town and Regional Planning, no. 75 , pp. 3-5.

\section{Municipal urban land release and acquisition - SALGA's proposals to facilitate spatial transformation and inclusive economic growth through efficient urban land governance and management approaches}

DOI: $h t t p: / / d x . d o i . o r g / 10.18820 / 2415-0495 / t r p 75 i 1.2$

Report compiled by Neo Molefe and Seana Nkhahle (South African Local Government Association) November 2019

\section{INTRODUCTION}

At its 2016 National Conference, the South African Local Government Association (SALGA) resolved "to assist municipalities to facilitate spatial transformation and inclusive economic growth through the adoption of efficient approaches to urban land acquisition and release" (SALGA, 2016). At the 2018 National Member's Assembly, SALGA made 8 resolutions that are a direct response to the long-outstanding urban land reform question that the country has been battling to address (SALGA, 2018). SALGA's proposals on urban land governance and management approaches will enable municipalities to proactively negotiate better development outcomes.

Despite the service delivery gains made since the democratic transition in 1994, the objectives of spatial transformation that enables equal access to land, the right of land use, sustainable development and inclusive economic growth have not been reached, as was expected. Many poor urban communities continue to be structurally excluded from urban land markets. The State has not yet fully explored its developmental mandate and has not sufficiently leveraged its ownership of strategically located land in order to facilitate the transformation of fragmented urban spaces (SALGA, 2017).

As a result, SALGA has made proposals that municipalities and their partners in and outside of the state can introduce as strategies for their respective land administration, management and governance processes in order to promote inclusive economic growth and to facilitate spatial transformation. Direction is given in the National Development Plan Vision 2030 which calls for "a long-term perspective on spatial transformation ... while addressing short-term needs" (NPC, 2012). Similarly, the Integrated Urban Development Framework (IUDF) defines strategies to effect spatial transformation and reverse inefficient spatial patterns. The IUDF approach proposes an urban growth model of compact, connected and coordinated cities and towns with coordinated investments in people and places (COGTA, 2016).

This commentary will not dwell on the research process followed, or the case studies explored as this has been set out in the Final Report entitled "Municipal Urban Land Release and Acquisition - Proposals to Facilitate Spatial Transformation and Inclusive Economic Growth through Efficient Urban Land Governance and Management Approaches - April 2019". This commentary focuses on the 8 resolutions that have been made by SALGA to facilitate spatial transformation and inclusive economic growth.

\section{OVERVIEW}

As the largest landowner in the country, the State has struggled to advance its developmental mandate and to facilitate foreign direct investment by leveraging strategically located State-owned land (SALGA, 2017). Urban land market participants continue to interact without effective alignment to the country's long-term goals as informed by, among others, the Bill of Rights entrenched in the Constitution of the Republic of South Africa, with specific reference to equity and inclusive growth (RSA, 1996).

It is important to analyse the urban land management issues and challenges that are hampering urban land reform, spatial transformation, and inclusive economic growth efforts of the State. Identifying these challenges assisted SALGA to develop proposals that municipalities can introduce as strategies in their respective landadministration, -management and -governance processes, in order to promote inclusive economic growth and facilitate spatial transformation.

\section{SALGA'S 8 RESOLUTIONS}

This section briefly explores the 8 resolutions made by SALGA during its 2018 National Member's Assembly.

1: Municipalities should have the right of first refusal on State-owned and SOE-owned land disposal.

Local government is best placed to evaluate the appropriateness of land for developmental purposes. As such, municipalities should have the right of first refusal to acquire state-owned land and land owned by State-Owned Entities (SOEs) when the State and SOEs intend to dispose of their land. SALGA resolved at its 2018 National Members Assembly that land negotiations with the State and SOEs should be preceded by extensive land audits and land needs assessments by municipalities.

The municipal land needs assessments should be informed by, and enable the implementation 
of, the spatial transformation and inclusive economic growth objectives of municipal Spatial Development Frameworks (SDFs) and Integrated Development Plans (IDPs). SALGA's 2018 National Member's Assembly further resolved that municipalities should be actively involved in all land audits conducted by SOEs, State departments, and other spheres of government. All land audits conducted by the Department of Agriculture, Land Reform and Rural Development (DALRRD), the Department of Public Works (DPW), the Department of Human Settlements (DHS) through the Housing Development Agency (HDA) and other stakeholders should include extensive information dissemination to municipalities.

Legislation is already in place to ensure the transfer of land to municipalities at subsidised monetary value if socio-economic factors are considered. The process to dispose State-owned land by provincial, national governments and SOEs already include the offering of such land to all organs of state, including municipalities. Municipalities should in theory thus have the first option to acquire State-owned land and SOE owned land when the State and SOEs intend to dispose of it. SALGA's national working group on planning and human settlements has gone a step further to propose that municipalities must proactively identify land that is required for spatial transformation with a view of acquiring this land. Land audits as well as urban land needs assessments that must be done within the context of SDFs need to precede engagements with SOEs and state departments.

\section{2: $\quad$ Advocating for less} bureaucracy and greater efficiency in SOE and State land transfer

To reduce red-tape, it is proposed that SOEs and the DPW delegate more decision-making powers regarding land disposal to regional / provincial offices, in particular land that has been identified as non-core SOEs and State land. A comprehensive database on government landownership needs to be developed and maintained, in order to enable municipalities to easily identify the owner of the land they want to acquire. The maintenance and management of such a data base, however, needs to run parallel with intergovernmental relations (IGR) processes to ensure coordination with the relevant department or SOE.

Municipalities should develop and implement clear procedures for land acquisition when land has been identified for certain needs or opportunities.

\section{3: $\quad$ Funding urban land acquisition for spatial transformation}

Municipalities should explore the use of expropriation of urban land. Non-financial compensation should also be explored (for example, land use and development incentives, investment incentives, land banking/land swops, and so on). On initiating a land acquisition process, municipalities should determine whether the land that is earmarked for acquisition may be transferred in one of two ways:

Financial acquisition process: This would include, through a negotiated price, grant support purchase (for example, Urban Land Grant, Human Settlement Development Grant and/or Urban Settlements Development Grant [USDG]), or a land lease agreement.

Non-financial acquisition process: This could be by means of landuse development incentives; investment incentives; land banking (land swop), or expropriation without compensation (utilization of current legislation).

\section{4: Municipal urban land acquisition should lead to negotiated development outcomes}

The terms of land transfer should be case and context specific and be supported by legislation and council-approved policies. Municipalities may enter into land transfer negotiations with private landowners (that is, individual landowners, corporations/companies, cooperatives, associations, trusts, and so on) and agree on reasonable terms for the transfer of land to municipalities. The Auditor General's Municipal Audit Results Report of June 2019 indicate that a significant number of municipalities are financially constraint due to various reasons which include historical and new factors (Auditor General South Africa, 2019). As such, municipalities need to explore investment and development incentives, that may be applicable, as compensation for private land acquired. Municipal land acquisition should lead to negotiated development outcomes that are anchored by the principles set out in the property and housing clauses of the Bill of Rights, as well as Sections 25 and 26 of the Constitution of the Republic of South Africa (RSA, 1996).

\section{5: Capacity building is required to create efficient municipal land administration and governance}

Technological and human resources capacity constraints hamper local government's ability to efficiently acquire, dispose and manage land. Municipalities should have access to up-to-date and credible data from the Deeds Office, Office of the Chief Surveyor General, Office of the Valuer General as well as geo-informatic data. Access to "live" data from these sources need to be prioritised.

Municipalities should employ professional town planners, land surveyors and other real estate professionals that form part of the land management and administration value chain in order to assist in land management roles.

A parallel training programme should be implemented to build the needed capacity in municipalities. Capacity building should be supported by good Information and Communication 
Technology including Geographic Information Systems (GIS). Capacity building will allow municipalities to be strategic in their land acquisition and disposal approaches and will enable them to negotiate better development outcomes.

\section{6: Engagement with traditional authorities}

Processes relating to the administration, planning and development of land under the custodianship of traditional authorities remains unclear and uncertain. It is often argued that land under the custodianship of traditional authorities cannot be formalized and sold to individual households. Traditional authorities must be engaged by the Department of Cooperative Governance and Traditional Affairs (COGTA) and the DALRRD in order to provide clear guidance on land administration and development processes. Sound legal advice and guidelines are required in this regard.

\section{7: $\quad$ Advocating for an integrated land administration system}

Good governance in urban land management and administration is required to create an efficient system of urban land acquisition and disposal. A structured, comprehensive and integrated land administration system is the backbone of an efficient approach to land acquisition and release, as well as government's urban land reform efforts. It is proposed that a land administration system be set up that integrates all spatial and land information that is currently held by different government departments, different spheres of government, SOEs, as well as research and academic institutions. The land administration system should be easily accessible to all spheres of government, state-owned entities and all members of the public. Municipalities should have access to up-to-date and credible data from the Deeds Office, Office of the Surveyor General, Office of the Valuer General as well as geo-informatic data.
The access of "live" data from these sources need to be prioritised

The DALRRD should be encouraged to support any organ of the state, especially municipalities that is unable to gather, submit, or develop and manage adequate data.

\section{8: Facilitation of public discourse and debate on land reform, as well as support for the development of national urban land policy}

SALGA supports the convening of the National Urban Forum and the National Urban Summit to unpack urban land debates and to coordinate and consolidate urban land reform efforts by the State. A national urban land policy is required in order to guide all spheres of government on the appropriate approaches, programmes and strategies that government needs to employ in order to ensure that inter-state land transfers are better coordinated and more efficient. Moreover, clear guidelines are required on how government can acquire privately owned land in a manner that promotes the public good but does not impede activities in urban and rural land markets.

\section{CONCLUSION}

This initiative forms part of a longer term initiative led by SALGA to empower municipalities to improve the way in which cities and towns address land reform, spatial transformation, as well as land governance and management. SALGA's initiative supports the NDP's proposals of a concerted effort by all spheres of government to facilitate spatial transformation and begins to give effect to the land-governance and -management policy priority actions of the IUDF.

\section{REFERENCES}

AUDITOR GENERAL SOUTH AFRICA. 2019. Municipal audit results. June, Pretoria: Auditor General South Africa.
COGTA (COOPERATIVE GOVERNANCE AND TRADITIONAL AFFAIRS). 2016. Integrated Urban Development Framework - A new deal for South African cities and towns. Pretoria: Department of Cooperative Governance and Traditional Affairs.

NPC (NATIONAL PLANNING COMMISSION). 2012. National Development Plan 2030 - Our futuremake it work. Pretoria: The Presidency.

RSA (REPUBLIC OF SOUTH AFRICA). 1996. The Constitution of the Republic of South Africa (Act 108 of 1996). Pretoria, Republic of South Africa.

SALGA (SOUTH AFRICAN LOCAL GOVERNMENT ASSOCIATION). 2016. SALGA National Conference. Johannesburg: South African Local Government Association.

SALGA (SOUTH AFRICAN LOCAL GOVERNMENT ASSOCIATION).

2017. Request for proposals for the appointment of a service provider to develop urban land release and acquisition strategies for municipalities to facilitate spatial transformation and inclusive economic growth on behalf of SALGA. Pretoria: South African Local Government Association.

SALGA (SOUTH AFRICAN LOCAL GOVERNMENT ASSOCIATION).

2018. Research on municipal urban land acquisition and release. Durban: South African Local Government Association. 